DOI: 10.20472/IAC.2018.043.042

\author{
NADHAKAN SHINNARANANTANA
}

Marketing Department, Kasetsart University, Thailand

\title{
INTERNET SHOPPING AND BUYING BEHAVIOR OF CLOTHING AND ACCESSORIES BY YOUNG SINGLE CONSUMER IN BANGKOK, THAILAND
}

\begin{abstract}
:
Nowadays clothing retailers have using multichannel of distribution, especially they are more focus on Internet shopping via website and application such as Instagram and Facebook fanpage. Because of increasing of internet usage rate of consumers. The use internet for several activities such as entertainment, searching for information, social media and also shopping. The clothing and accessories business are very fast moving industry. Their market growth are in the third rank follow food industry and department store. This study aim to explore marketing factors influencing buying behavior of young single consumer in clothing and accessories business via internet and social network. The samples of this research are young single consumer in Bangkok, Thailand by using convenience sampling and get 400 samples. Using questionnaire as an instrument and distribute via internet. The primary data was analyzed by SPSS program.

The result of this research shows that the most popular product is blouses and fashion bags. The samples like to shop online because of a new trend and it provide product variety and resonable price. Moreover, online shopping provide convenience for them both time and money. Sales promotion of the shop is the most important to encourage sale volume. They shopping via Instagram and company website. Therefore, the reliability and trust of company are the most important for their decision making.

The result of this research suggests that clothing and accessories companies should always maintain their product variety and up to date fashion with reasonable price. Purchase process is easily and trustworthy. Moreover, using sales promotion can booth up sale.
\end{abstract}

\section{Keywords:}

Clothing and accessories business, Internet Shopping, Buying Behavior, Young single, Bangkok Thailand

JEL Classification: M31 